\title{
Regulation of the PMP22 Gene through an Intronic Enhancer
}

\author{
Erin A. Jones, ${ }^{1}$ Camila Lopez-Anido, ${ }^{3}$ Rajini Srinivasan, ${ }^{3}$ Courtney Krueger, ${ }^{3}$ Li-Wei Chang, ${ }^{4}$ Rakesh Nagarajan, ${ }^{4}$ \\ and John Svaren ${ }^{2,3}$ \\ ${ }^{1}$ Program in Cellular and Molecular Biology, ${ }^{2}$ Department of Comparative Biosciences, and ${ }^{3}$ Waisman Center, University of Wisconsin, Madison, \\ Wisconsin 53705, and ${ }^{4}$ Department of Pathology and Immunology, Washington University School of Medicine, Saint Louis, Missouri 63110
}

Successful myelination of the peripheral nervous system depends upon induction of major protein components of myelin, such as peripheral myelin protein 22 (PMP22). Myelin stability is also sensitive to levels of PMP22, as a 1.4 Mb duplication on human chromosome 17, resulting in three copies of PMP22, is the most common cause of the peripheral neuropathy Charcot-Marie-Tooth disease. The transcription factor Egr2/Krox20 is required for induction of high level expression of Pmp22 in Schwann cells but its activation elements have not yet been determined. Using chromatin immunoprecipitation analysis of the rat $P m p 22$ locus, we found a major peak of Egr2 binding within the large intron of the Pmp22 gene. Analysis of a 250 bp region within the largest intron showed that it is strongly activated by Egr2 expression in reporter assays. Moreover, this region contains conserved binding sites not only for Egr2 but also for Sox10, which is also required for Schwann cell development. Our analysis shows that Sox10 is required for optimal activity of the intronic site as well as PMP22 expression. Finally, mouse transgenic analysis revealed tissue-specific expression of this intronic sequence in peripheral nerve. Overall, these data show that Egr 2 and Sox 10 activity are directly involved in mediating the developmental induction of $P m p 22$ expression.

\section{Introduction}

In the peripheral nervous system, the lipid-rich myelin sheath formed by Schwann cells plays a vital role in axonal function and stability. The myelin sheath is composed of many structural proteins required for the compact structure of myelin and the genes encoding such proteins are highly regulated during development. Genetic defects in the function or level of myelin genes can be detrimental and lead to peripheral neuropathy. CharcotMarie-Tooth disease (CMT) is the most common inherited peripheral neuropathy, affecting $\sim 1$ in 2500 people. The most common cause of CMT is a $1.4 \mathrm{Mb}$ duplication of human chromosome 17, containing the peripheral myelin protein 22 (PMP22) gene (classified as CMT type 1A), and a deletion of the same region leads to another type of peripheral neuropathy: hereditary neuropathy with liability to pressure palsies (Lupski et al., 1991; Chance et al., 1993; Suter and Scherer, 2003). Pmp22 is a tetraspan protein required for stable myelination (Adlkofer et al., 1995) and a number of rodent models for CMT1A have shown that transgenic overexpression of Pmp22 causes peripheral neuropathy (Huxley et al., 1996; Magyar et al., 1996; Sereda et al., 1996; Huxley et al., 1998;

\footnotetext{
Received Nov. 8, 2010; revised Jan. 17, 2011; accepted Jan. 21, 2011

This work was supported by grants from the Charcot-Marie-Tooth Association, National Institutes of Health (R01 HD41590), and its American Recovery and Reinvestment Act supplement (HD041590-09S1) to J.S., and a core grant to the Waisman Center from the National Institute of Child Health and Human Development (P30 HD03352). E.A.J. was supported by the Wayne and Jean Roper Distinguished Graduate Fellowship. We thank Richard Quarles for providing the S16 cell line and Alyssa Johnson, Jennifer Abraham, Gennifer Mager, Holly Hung, and Sung-Wook Jang for technical assistance. We also thank Albee Messing for assistance with transgenic analysis.

The authors declare no competing financial interests.

Correspondence should be addressed to John Svaren, 1500 Highland Avenue, Waisman Center, University of Wisconsin, Madison, WI 53705. E-mail: jpsvaren@wisc.edu.

DOI:10.1523/JNEUROSCI.5893-10.2011

Copyright $\odot 2011$ the authors $\quad 0270-6474 / 11 / 314242-09 \$ 15.00 / 0$
}

Robertson et al., 2002). Importantly, lowering expression of Pmp22 improves myelination in rodent models of CMT1A (Perea et al., 2001; Sereda et al., 2003; Passage et al., 2004).

Pmp22 is highly upregulated along with other myelin genes in Schwann cells during myelination as well as during remyelination following nerve crush injury (Snipes et al., 1992; Notterpek et al., 1999). Two transgenic studies identified overlapping upstream segments that lead to Schwann cellspecific expression (Maier et al., 2003; Orfali et al., 2005). This upstream region was shown to recapitulate the later expression of endogenous Pmp22 and has been named the late myelination Schwann cell-specific element (LMSE) (Maier et al., 2003). The region(s) responsible for early developmental expression have yet to be identified.

Early growth response 2 (Egr2/Krox20, hereafter referred to as Egr2) is a key regulator of myelin genes during early development (Topilko et al., 1994; Le et al., 2005b; Decker et al., 2006) and is also required for induction of Pmp22 (Nagarajan et al., 2001; Le et al., 2005a). Sox10 is required at several stages of Schwann cell development (Kuhlbrodt et al., 1998; Britsch et al., 2001; Schreiner et al., 2007; Finzsch et al., 2010) but has not been shown to directly regulate Pmp22. Interestingly, Sox10 binds near Egr2 at several loci in myelin genes (Jang et al., 2010) and has been shown to function synergistically with Egr2 at the myelin protein zero (Mpz) locus (Bondurand et al., 2001; Denarier et al., 2005; LeBlanc et al., 2006; Jang and Svaren, 2009). Because of their fundamental role in Schwann cell biology (Svaren and Meijer, 2008), we hypothesize that identifying the Egr2/Sox10 regulated sites will reveal critical regulatory elements within PMP22. Here we use chromatin immunoprecipitation (ChIP) of Egr2 and Sox10 to identify a novel enhancer that drives Schwann cellspecific expression of Pmp22. 
Table 1. Primer sets used in quantitative PCR

\begin{tabular}{lll}
\hline Name & Forward primer & Reverse primer \\
\hline$-7 \mathrm{~kb}$ & TCTGAGCTTTCTCTCTCCCACAG & TCCCAGGATGAAGTGCATCTT \\
$-2 \mathrm{~kb}$ & AGGCCCGCCTCCTGCACACG & TTTGCGTCGCTGCAGAAG \\
$+5 \mathrm{~kb}$ & TTCCTCAGGTGAGCAAAGTTTG & AAGGCCCCACATGGATA \\
$+6.5 \mathrm{~kb}$ & CCTGGTTTTTGATTTCCATTTTT & CAGGCCAGGGAAATCAAGAC \\
$+8.5 \mathrm{~kb}$ & CCCAGGCCACCTTCTCAGA & ACCAATGCCCTACAGTTCTAATGTT \\
$+11 \mathrm{~kb}$ & CACTGGCCTCTGGGCAAGT & GAAACAATGTGGCTTTGCTC \\
$+16 \mathrm{~kb}$ & TATTTTTGCTTTCTGGAGATGTTCCT & GGAGAGGCTTCCAAACTATGTATTG \\
$+24 \mathrm{~kb}$ & TCCCCCTCTATCGCAAACC & TGAGTTAAGTGAGCAGTACCTATTGG \\
Luciferase & GGCTACTTGATCTGCGGCTTT & TCCTCCTCGAGCGGTACAT \\
End Pmp22 & GAGGAAGGGGTACACCATTG & GCAACACTAGCACCGCGAT \\
End Mpz & CCCTGGCCATTGTGGTTTAC & CCATTCACTGGACCAGAAGGAG \\
Hmgcr & GGATGGTACCGGTGCTCT & AGAAACGACTGTAGCTC \\
\hline
\end{tabular}

\section{Materials and Methods}

Chromatin immunoprecipitation. ChIP assays on pooled male and female rat sciatic nerve at postnatal day (P)15 and the S16 cell line were performed as previously described (Jang et al., 2006; Jang and Svaren, 2009), except that the S16 cell line was cross-linked in PBS containing $1 \%$ formaldehyde. In addition, the herring sperm DNA in the blocking procedure was omitted in the in vivo ChIP assays. The antibodies used in this study include Egr2 (Covance PRB-236P), Sox10 (Santa Cruz Biotechnology sc-17342X), and control IgG (normal rabbit IgG, Millipore 12-370; normal goat IgG, Santa Cruz Biotechnology sc-2028). Following ChIP, quantitative PCR was performed in duplicate to calculate the fold recovery of a given segment relative to the nonspecific control, using the comparative $\mathrm{Ct}$ method (Livak and Schmittgen, 2001). All the primers used in this study are listed in Table 1 . All experiments on rats/mice were performed in strict accordance with experimental protocols approved by the Institutional Animal Care and Use Committee, University of Wisconsin, School of Veterinary Medicine.

ChIP analysis using tiled microarrays. To combine ChIP with microarray analysis, amplicons were first generated from ChIP products by whole genome amplification (Sigma). Labeling of the samples with Cy5 (Egr2; Covance) or Cy3 (IgG), followed by microarray hybridization, was performed as described previously (Jang and Svaren, 2009; Jang et al., 2010) by Nimblegen, using a custom microarray designed with isothermic probes staggered by 17 bp over the Pmp22 locus. Coordinates of tiled regions are derived from the $\mathrm{Rn} 4$ genome build. Gaps in the tiling represent repetitive DNA regions for which unique probes could not be designed. The enrichment ratio of Cy5 to Cy3 was plotted on a $\log _{2}$ scale, further processed by baselining all peaks to $1 \%$ of the highest peak in the window, and displayed a moving average using a window size of five probes. Peak finding was performed using the NimbleScan (Nimblegen) software, with a false discovery rate of 0.05 .

Formaldehyde-assisted isolation of regulatory elements. The formaldehydeassisted isolation of regulatory elements (FAIRE) assay on the S16 rat Schwann cell line was performed by first rinsing confluent cells with PBS and then cross-linking in PBS containing 1\% formaldehyde for 5 min at room temperature $\left(22^{\circ} \mathrm{C}\right)$. Glycine was added to $125 \mathrm{~mm}$ and incubated for $5 \mathrm{~min}$ at room temperature. After washing twice with cold PBS, the cells were harvested, pelleted, and frozen at $-80^{\circ} \mathrm{C}$. The cell pellet was thawed and sonicated on ice using the Bioruptor (Diagenode) set on high (30 s on, $30 \mathrm{~s}$ off; for $20 \mathrm{~min}$ ) in lysis buffer (150 mм NaCl, 10\% glycerol, 50 mм Tris pH 8.0, 2\% Triton, 1\% SDS, 1 mm EDTA) containing protease inhibitor mixture ( $5 \mu \mathrm{l}$ of mixture per milliliter of buffer) (Sigma). The lysate was cleared by centrifugation and unbound DNA was extracted with phenol:chloroform and ethanol precipitated, as previously described (Giresi and Lieb, 2009). The protocol only differed in that $\mathrm{NaCl}$ was used in the ethanol precipitation. Twenty percent of the cross-linked chromatin was used as an input control by reversing the cross-links at $65^{\circ} \mathrm{C}$ overnight before phenol:chloroform extraction. The samples were analyzed using quantitative PCR with the same primer sets used in ChIP (Table 1), performed in duplicate to calculate the relative expression, of a given segment relative to the input control, using the comparative $\mathrm{Ct}$ method (Livak and Schmittgen, 2001).

Transfection assays. The B16 (mouse melanoma) cell line was grown and transfected as described previously (Jones et al., 2007; LeBlanc et al., 2007). The reporter constructs contain the following coordinates from human chromosome 17 (hg18Mar. 2006 build in UCSC Genome Browser), cloned upstream of the pGL4 luciferase reporter containing the minimal E1B TATA promoter except the PMP22 $-2 \mathrm{~kb}$ construct that contains the native PMP22 P2 promoter; PMP22 -7 kb: 15,113,094-15,114,102; PMP22 - 2 kb: 15,106,498-15,106,933; PMP22 +5 kb: 15,098,299-15,098,685; PMP22 +8.5 kb: 15,094,46615,094,975; PMP22 + 11 kb: 15,091,959-15,092,201; PMP22 + 16 kb: 15,086,052-15,086,906; PMP22 + 24 kb: 15,075,138-15,075,801. The mutations of the PMP $22+11 \mathrm{~kb}$ reporter were made using site-directed mutagenesis. The individual Sox 10 sites were changed to $G$ at positions 4 and 5 on the CA-rich strand, which has been previously reported to abrogate Sox 10 binding to DNA (Bondurand et al., 2001). The Egr2 sites were mutated to A at position 6 of the G-rich strand, which has previously been shown to abolish binding (Choo et al., 1997).

siRNA treatment and Western blot analysis. Either siRNA directed toward Sox10 (4390771; Ambion) or a negative siRNA control (Negative control \#2, AM4613; Ambion) were transiently transfected into S16 cells with the Amaxa system (Lonza) using the rat neuron nucleofection solution. The transfected cells were incubated for $48 \mathrm{~h}$ before harvesting RNA using Tri Reagent (Ambion), and quantitative PCR was performed in duplicate to calculate the relative expression, using the comparative $\mathrm{Ct}$ method (Livak and Schmittgen, 2001).

Lysates from siRNA-treated S16 cells were analyzed by immunoblotting for Sox10 and Pmp22 using a 1:1000 dilution of Sox10 (Santa Cruz Biotechnology) and a 1:1000 dilution of Pmp22 (Abcam). The membranes were probed with horseradish peroxidase-conjugated anti-rabbit secondary antibody (Jackson Laboratories) at a dilution of 1:10,000. Luminescence was detected with ECL Plus (Invitrogen) using the Alpha Innotech Fluorochem HDII imaging system.

Bioinformatic analysis. Regions conserved between humans, rats, and mice in a $40 \mathrm{~kb}$ window surrounding the Pmp22 locus were searched for Egr2/Sox10 binding sites using a conserved composite element module previously described (Jones et al., 2007).

Transgenic mice. The transgene used in this study contains the following coordinates from the human genome (Mar. 2006 build in UCSC Genome Browser), cloned upstream of the pGL4 luciferase reporter containing the mouse Hsp68 promoter: chr17: 15,090,965$15,092,611$. The transgene was linearized by restriction digestion (KpnI and SalI) and microinjected into the pronucleus of FVB/N one-cell embryos by the University of Wisconsin Waisman Center Rodent Models Core. Relative copy number of each founder was determined by using quantitative PCR to normalize the transgene to an endogenous gene, Hmgcr. At P4, P12, and P30, various tissues were collected from both male and female mice for luciferase expression analysis by quantitative reverse transcription PCR.

Immunohistochemistry. Frozen sections of mouse sciatic nerve $(6 \mu \mathrm{m})$ were fixed in 4\% paraformaldehyde in PBS for $15 \mathrm{~min}$ at room temperature. After the sections were rinsed with PBS, they were incubated with permeabilizing solution $(0.06 \%$ Triton X-100 in PBS) for $20 \mathrm{~min}$. They were rinsed three times with PBS and incubated in blocking solution (5\% goat serum, $1 \%$ BSA in PBS) for $1 \mathrm{~h}$. Sections were incubated with antifirefly luciferase (Luc-17) mouse monoclonal antibody (1:100; Abcam) for $1 \mathrm{~h}$. They were rinsed three times with PBS and incubated with Alexa488 secondary antibodies for $1 \mathrm{~h}$. After the sections were rinsed once with PBS, they were incubated with Hoescht 33258 (1:1000; Fisher Scientific) in PBS for $1 \mathrm{~min}$ and then rinsed five times with PBS. The sections were mounted on slides using Fluoromount-G mounting medium (Southern Biotech). Immunofluorescent images were visualized via a Nikon C1 confocal microscope.

\section{Results}

Identification of Egr2 binding sites in Pmp22

PMP22 is expressed from two different promoters, P1 and P2, transcribing exon $1 \mathrm{~A}$ and exon $1 \mathrm{~B}$, respectively, which result in 
two mRNAs that differ only in their 5' noncoding region (Bosse et al., 1994; Suter et al., 1994). Both the P1 and P2 promoters are upregulated during myelination, but expression from $\mathrm{P} 1$ is Schwann cell-specific, whereas P2 is expressed in other tissues, such as brain, heart, lung, and gut. As myelination progresses, the transcript originating from $\mathrm{P} 1$ becomes the predominant form in rodent peripheral nerve, whereas the ratio of $\mathrm{P} 1$ to P2 in human peripheral nerve is approximately equal (Suter et al., 1994). Transfection studies of Pmp22 expression have shown that the P1 promoter can drive expression of a reporter in Schwann cells (Suter et al., 1994; Sabéran-Djoneidi et al., 2000; Hai et al., 2001). However, additional regulatory elements are involved since the $\mathrm{P} 1$ promoter is unable to independently drive consistent expression in peripheral nerve of transgenic mice (Maier et al., 2003).

Since Egr2 activates Pmp22 expression (Nagarajan et al., 2001; Le et al., 2005a), we sought to identify Egr2 binding sites as a means to discover critical Pmp22 enhancer elements. We therefore adapted Egr2 ChIP assays in the S16 rat Schwann cell line for analysis with a tiled microarray (ChIP-chip) containing $200 \mathrm{~kb}$ surrounding the rat Pmp22 gene (Fig. 1A). The $\mathrm{S} 16$ cell line expresses high levels of myelin genes, including Pmp22, comparable to those in myelinating Schwann cells (Hai et al., 2002). Egr2 ChIP DNA was cohybridized to the custom array along with control IgG ChIP DNA, and the fluorescence ratio was plotted relative to the position within the Pmp22 locus. The results show a major peak at $+11 \mathrm{~kb}$ (relative to the translation start site) within the largest intron of the Pmp22 gene, along with some more minor peaks distributed throughout the gene.

Several sites with various levels of Egr2 binding were chosen for further analysis (Fig. $1 A$, arrows). The site at $-7 \mathrm{~kb}$ is within a larger region previously shown to drive Schwann cell-specific expression in mice (Maier et al., 2003; Orfali et al., 2005). The -2 $\mathrm{kb}$ region is just upstream of the $\mathrm{P} 2$ promoter, expressing exon 1b. Several intronic sites in uncharacterized regions of $P m p 22$ were also chosen for further analysis, including the major peak at $+11 \mathrm{~kb}$. Egr2 binding at these sites was validated by quantitative PCR analysis of independent ChIP samples from the S16 cell line, revealing high levels of Egr 2 at $+11 \mathrm{~kb}$ relative to a control immunoprecipitation (Fig. $1 B$ ). Moreover, we also performed in vivo ChIP assays using $\mathrm{P} 15$ rat sciatic nerve, which is an optimal time point for detection of Egr2 binding by ChIP (Jang et al., 2006; Mager et al., 2008; Jang and Svaren, 2009). The in vivo ChIP assay demonstrated a significant level of binding at $+11 \mathrm{~kb}$, consistent with the ChIP assays in the S16 cell line (Fig. 1C). Many of the minor peaks in the ChIP-chip analysis do not exhibit significant Egr2 binding above background in quantitative PCR analysis of ChIP samples from S16 cells or in vivo. The $+11 \mathrm{~kb}$ region appears to be the predominant region for Egr2 binding during myelination.

\section{Activation of PMP22-derived segments in reporter assays}

To determine whether Egr2-bound regions have enhancer activity, many of the regions chosen for further analysis in the ChIP assay were tested for their response to Egr2 expression in a luciferase reporter assay. Segments were cloned upstream of a minimal TATA promoter driving luciferase except $-2 \mathrm{~kb}$, which contains the P2 promoter (Fig. 2A, arrows). As many of these segments contained conserved sequences, the homologous human sequences were used to create the reporter vectors.

The reporters were tested in the B16/F10 melanoma cell line, which expresses Sox10 (Kamaraju et al., 2002) but not Egr2 (Slutsky et al., 2003), for activation by cotransfection of an Egr2 expression construct. The $+11 \mathrm{~kb}$ reporter from the largest intron was highly activated in response to Egr2, whereas the other six reporters were not strongly activated. The $+11 \mathrm{~kb}$ region also showed the strongest Egr2 binding in the ChIP assays (Fig. 1), indicating that Egr2 binding is correlated with enhancer activity in this assay.

\section{Identification of functional Sox10 and Egr2 sites in the $+11 \mathrm{~kb}$ enhancer}

Analysis of the human $+11 \mathrm{~kb}$ element revealed four putative Egr2 sites and one putative dimeric Sox 10 site, which are variably conserved the in rat, mouse, and human genomes (Fig. $2 \mathrm{~B}$ ). The $+11 \mathrm{~kb}$ reporter construct used above was mutated to test the importance of these sites in Egr2 activation. The Egr2 sites were 
A

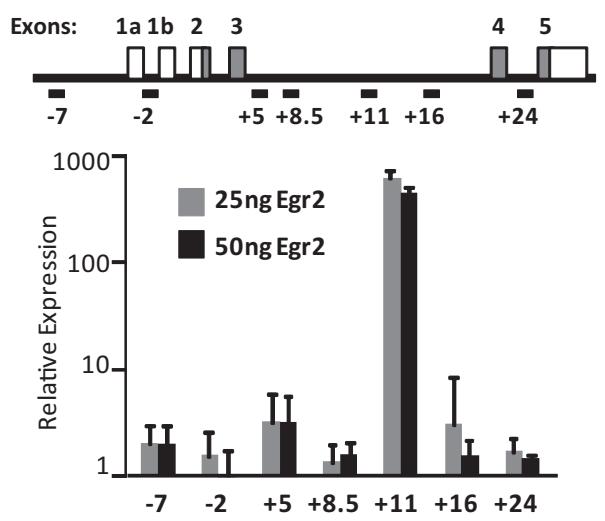

B

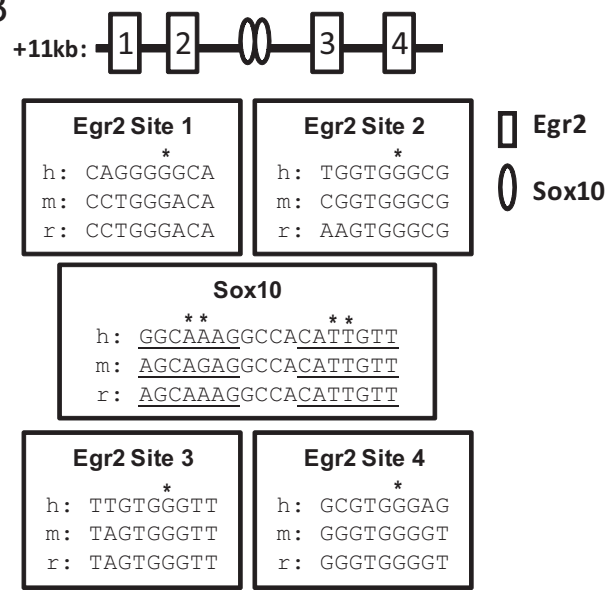

Figure 2. Reporter analysis of selected human PMP22 segments. $A$, The indicated segments of the human PMP22 gene were placed upstream of a luciferase reporter gene containing a minimal TATA element, except the $-2 \mathrm{~kb}$ reporter, which contains the PMP22P2 promoter. The PMP22 reporters were cotransfected in the B16/F10 cell line with expression plasmids for Egr2 ( 25 and $50 \mathrm{ng}$ ). Fold induction is calculated relative to the activity of each reporter alone and reported on a $\log _{10}$ scale. Error bars represent SD $(n=6)$. $\boldsymbol{B}$, The $+11 \mathrm{~kb}$ region of human PMP22 is diagramed with four putative Egr2 sites (numbered boxes) and one putative dimeric Sox10 site (ovals). The sequence alignments show conservation of the binding sites in humans $(\mathrm{h})$, mice $(\mathrm{m})$, and rats $(\mathrm{r})$. The monomeric Sox10 binding sites are underlined and the nucleotides mutated by site-directed mutagenesis are indicated $(*)$.

mutated to A at position 6 of the G-rich strand, which has previously been shown to abolish binding (Choo et al., 1997). When all four sites were mutated, the Egr2 activation was abolished (Fig. $3 A)$. To determine which of the four Egr2 sites are functional, the Egr2 sites were each mutated individually (Fig. 3B). Transfection analysis of the resulting promoter constructs showed that mutating Egr2 site 2 had the largest effect, whereas reporter activity was relatively unimpaired by mutation of sites 1 or 3 . There was an $\sim 50 \%$ decrease with mutation of site 4 .

Subsequently, reporter constructs were created in which all but one of the putative Egr2 sites were mutated (Fig. 3C). In this series, the construct containing Egr2 site 2 was most highly activated, yielding a 179-fold activation, which is approximately onefifth of the activity of the wild-type element. Egr 2 sites 3 and 4 support a lower level of activation in this assay, suggesting that they can mediate some of the Egr2 activation. In both sets of constructs, the Egr2 site 1 does not appear to contribute to reporter activity (Fig. $3 B, C$ ). Therefore, sites $2-4$ appear to be largely responsible for the strong activation of the $+11 \mathrm{~kb}$ element in transfection assays. Using a recently defined binding site
A
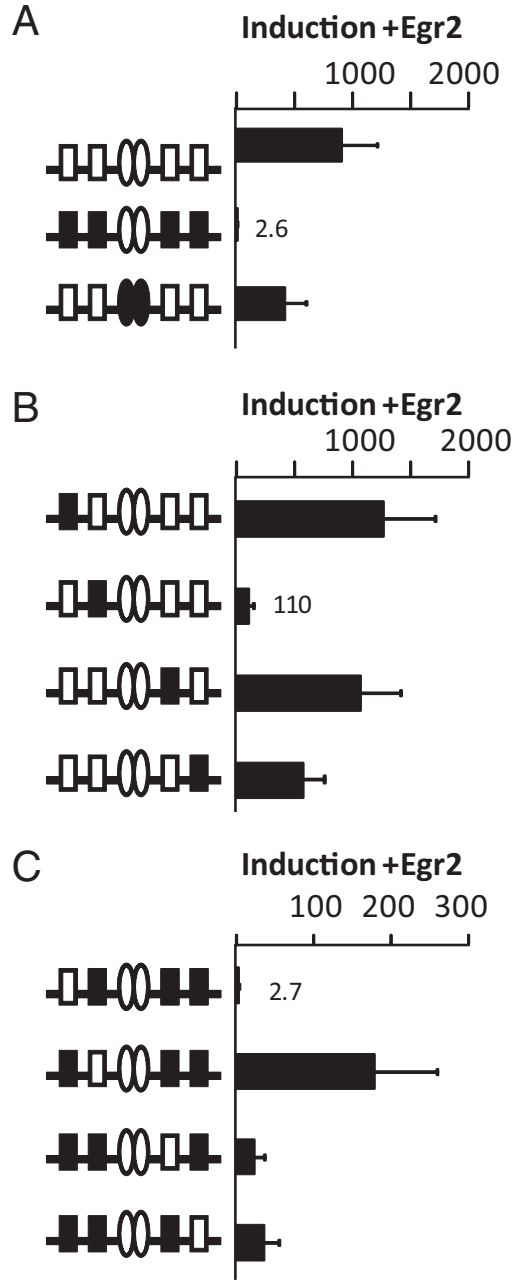

Figure 3. Functional analysis of Egr2 and Sox 10 sites within the $+11 \mathrm{~kb}$ enhancer. $\boldsymbol{A}$, Mutated sites are indicated by filled symbols, and the various mutant $+11 \mathrm{~kb}$ reporters were cotransfected in B16/F10 cells with expression plasmids for Egr2 $(25 \mathrm{ng})$. Fold induction is calculated relative to the luciferase activity of each reporter alone. Error bars represent $S D(n=$ 6). $\boldsymbol{B}$, The four Egr2 sites were mutated by site-directed mutagenesis, indicated by filled symbols. The reporters were cotransfected in B16/F10 cells with expression plasmids for Egr2 (25 ng). Fold induction, means, and SD $(n=6)$ are calculated as in $\boldsymbol{A}$. C, Reporter constructs were created in which all but one Egr2 site was mutated, indicated by filled symbols. The reporters were tested for Egr2 induction as in $\boldsymbol{B}(n=6)$.

matrix for Egr1 (Berger et al., 2006), which has an identical DNA binding domain to Egr2, sites 2 and 3 are most conserved, especially at the bases that are most critical for binding. Although Egr2 site 4 in the human sequence would be predicted to be a high affinity site, it is less well conserved in rat and mouse.

To determine whether the Sox10 site is functional, the adenines at positions 4 and 5 of the CA rich strand (AACAANG) were mutated to $\mathrm{G}$ in both sides of the dimeric Sox 10 site, which has previously been shown to disrupt Sox10 binding (Bondurand et al., 2001). Mutating the Sox10 sites lowered the Egr2dependent activation, suggesting that Egr2 activation requires Sox 10 binding at this site (Fig. $3 A$ ). Although the B16/F10 cell line expresses Sox10, cotransfection of $100 \mathrm{ng}$ of Sox 10 expression plasmid further activated the $+11 \mathrm{~kb}$ reporter 14 -fold \pm 2.4 . The Sox 10 mutation decreased Sox 10 activation of the $+11 \mathrm{~kb}$ reporter to 1.8 -fold \pm 0.3 , suggesting that this is a functional Sox 10 site and the $+11 \mathrm{~kb}$ element is dependent on both Egr 2 and Sox 10 for activation. 


\section{Sox10 regulates Pmp22}

Since the dependence of Pmp22 expression on Sox 10 activity has not been tested previously, we examined Pmp22 levels in S16 Schwann cells treated with siRNA directed against Sox10 (Fig. $4 A$ ). At $48 \mathrm{~h}$ after transfection, quantitative reverse transcriptase (RT)-PCR analysis revealed a significant decrease in Sox 10 mRNA levels, and Western analysis showed a decrease in Sox10 protein (Fig. 4A,B). This reduction was observed for both $P m p 22$ transcripts using primer sets specific for exons $1 \mathrm{a}$ and $1 \mathrm{~b}$. Similar results were obtained using two independent siRNAs directed toward Sox10 (data not shown).

Previous work has shown that Sox10 is required for expression of Egr2 in myelinating Schwann cells (Ghislain and Charnay, 2006; Finzsch et al., 2010; Reiprich et al., 2010). Consistent with these findings, Egr2 levels were reduced by Sox10 depletion in the $\mathrm{S} 16$ cell line. Since the effect of Sox 10 on Pmp22 expression could be mediated indirectly through regulation of Egr2, ChIP assays were used to detect Sox10 binding within the Pmp22 locus (Fig. 4C,D). ChIP assays were performed using an antibody directed against Sox10 in both the S16 rat Schwann cell line and in vivo using rat sciatic nerve. The Sox10 ChIP was analyzed using the same primer sets used to detect Egr2 occupancy and revealed that Sox10 coincides with Egr 2 binding at the $+11 \mathrm{~kb}$ site. However, we also observed Sox10 binding at other sites across Pmp22, with the highest amount of Sox10 binding at the $-7 \mathrm{~kb}$ site that resides within the previously defined LMSE (Maier et al., 2003).

To test the specificity of the Sox10 ChIP assays, the same assay was also performed in S16 cells in which Sox10 levels were depleted by Sox10 siRNA (Fig. 4C). For the sites examined, the percentage recovery was severely reduced, indicating that the ChIP assays detected specific binding of Sox10 to those sites. Accordingly, the Sox10 antibody detects a single band in the Western blot (Fig. $4 B$ ).

\section{Egr2 and Sox10 bound regions are in regions of open chromatin}

To further test for common characteristics of enhancer elements, FAIRE was used in S16 cells to identify areas of open chromatin (Giresi et al., 2007), which are typically present in regulatory regions (Felsenfeld and Groudine, 2003). This technique relies on the fact that enhancers often reside in nucleosome-depleted regions. Because DNA is most efficiently cross-linked to histones by formaldehyde, phenol extraction of protein-cross-linked DNA results in preferential enrichment of nucleosome-free regions of the genome. The FAIRE analysis shows that there is selective enrichment of DNA surrounding the $-7 \mathrm{~kb},-2 \mathrm{~kb}$, and $+11 \mathrm{~kb}$ regions, consistent with areas of open chromatin (Fig. 5). We expected the $-2 \mathrm{~kb}$ region to have open chromatin because it is directly upstream of the active P2 promoter (Hai et al., 2002), and FAIRE specifically enriches for nucleosome-free regions at promoters of highly transcribed genes (Hogan et al., 2006). Similar regions of open chromatin were found in a previous

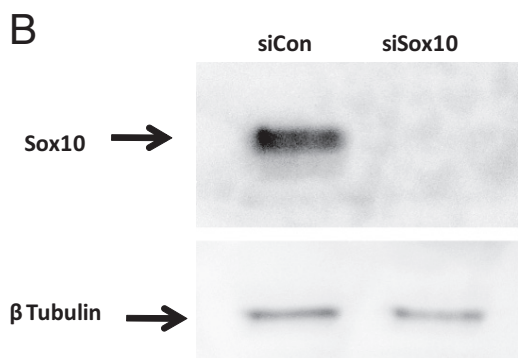

D
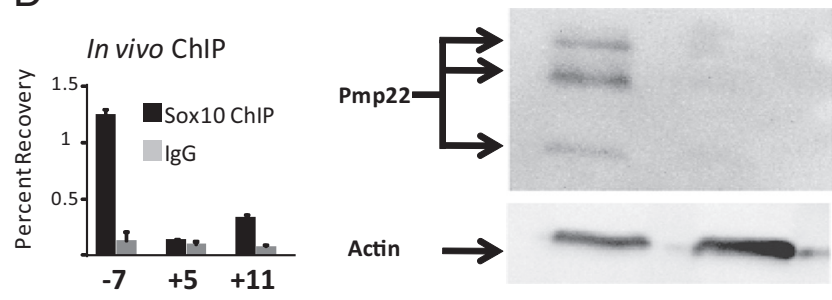

22 by Sox10 A S16 cells were transfected with siRNA targeted to Sox10. Quantitative RT-PCR was

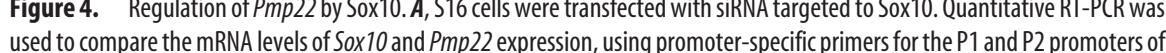
the Pmp22 gene. Levels in the Sox10 siRNA-treated cells (siSox10) were normalized to the negative control (siCon). Error bars represent SD $(n=3)$. $\boldsymbol{B}$, Protein lysates from S16 cells treated with the indicated siRNAs were blotted with antibodies directed

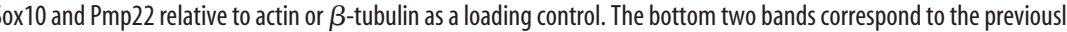
represent the SD of two technical replicates. The signal was enriched an average of 12 -fold at the $-7 \mathrm{~kb}$ site and an average of 3.5-fold at the $+11 \mathrm{~kb}$ site in three independent experiments.

study from our lab using in vivo FAIRE from P15 rat sciatic nerve (Jang et al., 2010). The regions of open chromatin at -7 $\mathrm{kb}$ and $+11 \mathrm{~kb}$ are consistent with the hypothesis that these are enhancer elements.

Sequence analysis of Egr2 and Sox10 sites in the Pmp22 locus The Pmp22 locus was also screened for conserved occurrences of a composite matrix containing consensus sequences for both Egr2 and dimeric Sox10 sites. Using a composite matrix provided a more reliable prediction of enhancer elements in myelin genes than identification of Egr2 or Sox10 sites alone (Jones et al., 2007). Performing this screen for composite sites conserved in mouse, rat, and human PMP22 genes identified three regions that contain the Sox/Egr2 binding module (Table 2). One region is at the $+11 \mathrm{~kb}$ site, a second is at the $-7 \mathrm{~kb}$ site, and the third is at $+45 \mathrm{~kb}$ in relation to the translation start site and far downstream of the $3^{\prime}$ end of Pmp22. The $+45 \mathrm{~kb}$ Egr2 sequence has an A at position 6 of the G-rich strand, which has previously been shown to abolish binding (Choo et al., 1997), making this a poor site. Our data have shown that the intronic enhancer at $+11 \mathrm{~kb}$ is regulated by Egr2 and Sox10, again showing that this composite matrix has predictive value. We did observe high levels of Sox10 binding at the $-7 \mathrm{~kb}$ sites, and there was a small response of this region to Sox10 in transfection studies (data not shown). However, reporter studies of this site failed to show any response to Egr2, and the ChIP data showed relatively low binding of Egr2. As mentioned, the $-7 \mathrm{~kb}$ region used here represents only a small portion of a larger region that has been shown previously to drive Schwann cell-specific expression (Maier et al., 2003; Orfali et al., 2005), so it is possible that Egr2-responsive elements are located elsewhere within this region. 

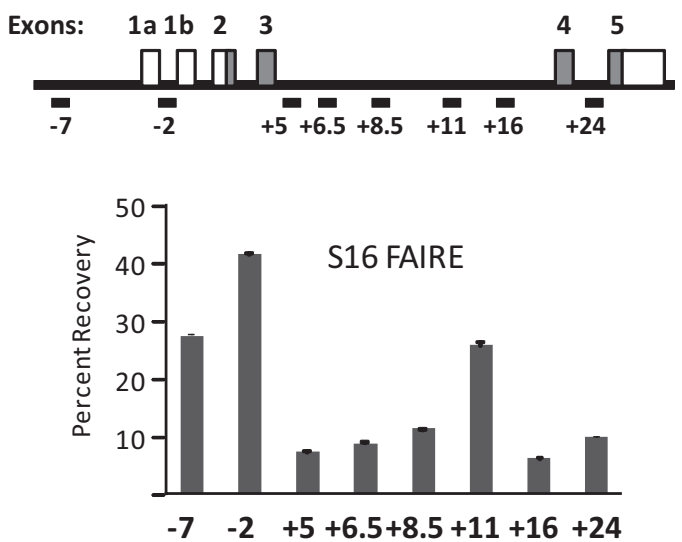

Figure 5. Analysis of open chromatin in the Pmp22 locus. A diagram of Pmp22 indicates regions chosen for FAIRE analysis, in which areas of open chromatin are selectively enriched by phenol extraction of cross-linked chromatin. The percentage recovery was calculated relative to total input. Error bars represent the SD of two technical replicates.

Table 2. Evolutionarily conserved SOX/EGR2 modules found in mouse Pmp22

\begin{tabular}{lclllll}
\hline $\begin{array}{l}\text { Name of } \\
\text { site }\end{array}$ & $\begin{array}{l}\text { SOX } \\
\text { position }\end{array}$ & $\begin{array}{l}\text { SOX } \\
\text { score }\end{array}$ & $\begin{array}{l}\text { SOX dimer } \\
\text { spacing (bp) }\end{array}$ & $\begin{array}{l}\text { EGR } \\
\text { position }\end{array}$ & $\begin{array}{l}\text { EGR } \\
\text { score }\end{array}$ & $\begin{array}{l}\text { Distance to SOX } \\
\text { site }\end{array}$ \\
\hline$-7 \mathrm{~kb}$ & -6533 & 9.54 & 4 & -6470 & 5.52 & 63 \\
$+11 \mathrm{~kb}$ & 11567 & 8.07 & 4 & 11492 & 4.72 & 75 \\
& & & & 11553 & 6 & 14 \\
& & & & 11689 & 6.81 & 122 \\
$+45 \mathrm{~kb}$ & 49424 & 8.51 & 4 & 49446 & 5.28 & 22 \\
\hline
\end{tabular}

Sites within a $100 \mathrm{~kb}$ window surrounding the mouse Pmp22 locus (chr11:62,909,000-63,009,000, mm9) were predicted using a conserved composite matrix described previously (Jones et al., 2007). Such sites conserved in human and rat genomes are shown. The sites are numbered relative to the mouse Pmp $22 \mathrm{P} 1$ promoter.

\section{The $+11 \mathrm{~kb}$ element drives tissue-specific expression}

The LMSE region upstream of $P m p 22$, comprising $\sim 3.5 \mathrm{~kb}$ surrounding the $-7 \mathrm{~kb}$ element, has been shown to drive tissue-specific expression of a lac $Z$ reporter in transgenic mice late in development (Maier et al., 2003). We hypothesized that the $+11 \mathrm{~kb}$ element could also drive tissue-specific expression and may account for earlier developmental expression of Pmp22. Transgenic injections were performed with the region surrounding the $+11 \mathrm{~kb}$ element driving a luciferase reporter with the Hsp68 promoter (Fig. 6A). This promoter has very low levels of expression in peripheral nerve and it has been used extensively to test tissue specificity of regulatory elements in transgenic experiments (Kothary et al., 1988; Rossant et al., 1991; Mandemakers et al., 2000; Forghani et al., 2001; Maier et al., 2003; Visel et al., 2009). Seven of 12 positive founders had luciferase expression in the sciatic nerve but not liver by quantitative RT-PCR analysis (Fig. 6B), suggesting that this region drives tissue-specific expression in Schwann cells. To determine the developmental regulation of the intronic enhancer, lines were developed from two of the founders, lines D and E, and sciatic nerve was sampled at P4 and P12 (Fig. 6C). Both lines had somewhat higher expression at $\mathrm{P} 12$ relative to $\mathrm{P} 4$, which is similar to two other endogenous myelin genes, $P m p 22$ and Mpz. P30 mice were also tested for luciferase expression and the expression differed no more than 2.5-fold compared with the expression at P12 (data not shown). Expression at P4 suggests that the $+11 \mathrm{~kb}$ region, at least in part, accounts for the earlier developmental expression of Pmp22 in myelinating Schwann cells, since transgenic studies of the upstream LMSE yielded undetectable levels of the reporters at P4 (Maier et al., 2003).
In addition to sciatic nerve and liver, we also sampled heart, lung, kidney, spleen, and brain from lines D and E, and used quantitative RT-PCR to detect luciferase mRNA in these tissues (Fig. 6D). Line E had very high expression in the lung, possibly due to insertion near an active enhancer element in lung. Expression in the sciatic nerve suggests that this element is important to Schwann cell expression of PMP22 and the residual activity of this $+11 \mathrm{~kb}$ element in other tissues suggests that it may play a role in the basal level of Pmp22 mRNA expression observed in other tissues (Suter et al., 1994). Finally, expression of the luciferase protein was observed by immunohistochemistry in sciatic nerve of a P50 mouse from line E (Fig. 6E).

\section{Discussion}

The activation of PMP22 is regulated spatially and temporally to achieve the critical levels of PMP22 required for proper myelin formation. Previous studies have characterized the regions upstream of the Pmp22 promoter that are critical to its regulation (Suter et al., 1994; Sabéran-Djoneidi et al., 2000; Hai et al., 2001; Maier et al., 2002, 2003; Orfali et al., 2005). However, Maier et al. indicated that other regions of $P m p 22$ are likely required, particularly for the early induction of Pmp22 during myelination. Using ChIP-chip analysis of $200 \mathrm{~kb}$ surrounding the Pmp22 gene, we found a novel $+11 \mathrm{~kb}$ intronic enhancer driven by both Egr2 and Sox10. Because the region upstream of Pmp22 has been shown to drive Schwann cell-specific expression late in development, we speculated that the $+11 \mathrm{~kb}$ enhancer may account for the earlier expression of Pmp22, and the transgenic data are consistent with this hypothesis. Since ChIP assays detect higher levels of Egr2 binding at $+11 \mathrm{~kb}$, a possible explanation for the earlier expression of the $+11 \mathrm{~kb}$ element in transgenic studies is that Egr2 has a higher affinity for this site. Therefore, Egr2 must accumulate to higher levels in myelinating Schwann cells to activate the upstream enhancer. However, these elements probably do not act in an isolated manner and it is likely that temporal regulation depends upon looping-mediated interactions between these two enhancers (and perhaps others) and the promoters that set the critical level of Pmp22 transcription.

Although the $-7 \mathrm{~kb}$ region was not activated by Egr 2 in reporter assays, it should be noted that the sequences that we used represent only a fraction of the previously reported $3.5 \mathrm{~kb}$ LMSE region (Maier et al., 2003), possibly explaining why it was not activated in our Egr2 activation assays. In the ChIP assays, we observed a high level of Sox10 binding at $-7 \mathrm{~kb}$, whereas Egr2 binding was higher at $+11 \mathrm{~kb}$. In fact, although the $-7 \mathrm{~kb}$ reporter did not respond to Egr2 in the transfection assay, it responded slightly to Sox10 (data not shown). This leads us to speculate that the varying strengths of Egr2 and Sox10 binding establish temporally regulated binding at each PMP22 enhancer and leads to more sensitive regulation of PMP22 during development.

Previous work has shown that Egr2 is required for Pmp22 expression (Nagarajan et al., 2001; Le et al., 2005a), but investigating the role of Sox10 in regulation of PMP22 in myelinating Schwann cells has been complicated because of the early embryonic lethality of Sox10-null mice (Britsch et al., 2001). Hypomorphic alleles and a conditional knock-out of Sox10 have been generated that permit further differentiation of Schwann cells (Schreiner et al., 2007; Finzsch et al., 2010), but these fail to activate Egr2 expression, consistent with previous studies showing that Sox10 binds to the myelinating Schwann cell enhancer of the Egr2/Krox20 gene (Ghislain and Charnay, 2006; Reiprich et al., 2010). The RNAi-mediated depletion of Sox10 in S16 cells 
similarly reduced Egr2 levels, indicating that Sox 10 depletion may indirectly affect Pmp22 expression through downregulation of Egr2. However, direct regulation of Pmp22 by Sox10 is supported by the detection of Sox10 binding in the Pmp22 locus by ChIP assays, and the observed effects of mutating the Sox 10 site in the +11 $\mathrm{kb}$ enhancer.

Both ascorbic acid and progesterone antagonists lower Pmp22 levels and improve the phenotype in mouse and rat models of CMT1A (Sereda et al., 2003; Passage et al., 2004). Ascorbic acid affects Pmp22 through inhibition of the cAMP pathway (Kaya et al., 2007) and although it has not been shown directly that Egr2 is involved, Egr2 is induced through the cAMP pathway (Zorick et al., 1996). In the case of progesterone antagonists, it also has not been shown directly to involve Egr2 and Sox10, but progesterone induces both Egr2 and Sox10 (Guennoun et al., 2001; Magnaghi et al., 2007) and they are presumably downregulated with progesterone antagonist treatment. Although it has not been shown whether Egr2 or Sox10 mediate the effects of ascorbic acid or progesterone antagonists, our data support a model of Pmp22 regulation, at least in part, through Egr2 and Sox10.

Other studies describe the interaction of Egr2 and Sox10 in regulatory elements in the Connexin 32 and Mbp genes (Bondurand et al., 2001; Denarier et al., 2005), and Egr2 and Sox10 bind cooperatively at an intronic regulatory element in $M p z$ and physically interact (LeBlanc et al., 2007). In addition, ChIP-chip analysis of a larger set of myelin genes revealed that Sox 10 colocalizes with Egr2 more often than would be expected by chance (Jang et al., 2010). Reporter analysis of the intronic element in Pmp22 revealed that Egr2 activation of this element is dependent upon Sox10. Furthermore, Pmp22 activation is sensitive to a dominant mutant of Egr2 (Nagarajan et al., 2001), which disrupts cooperative interactions between Egr2 and Sox10 (LeBlanc et al., 2007), suggesting that Egr2 and Sox 10 are working cooperatively at Pmp22. We previously proposed a composite matrix of Egr2 and Sox 10 binding sites as a means to predict regulatory elements in myelin genes (Jones et al., 2007). Interestingly, application of this matrix to the Pmp22 gene identified only three such sites in which Egr2 and Sox10 binding sites are conserved. One was within the LMSE segment upstream of the gene, and the other coincided with the intron regulatory element that we have characterized. Overall, these data are consistent with a model of Egr2 and Sox 10 binding in myelin loci, where both Egr2 and Sox 10 are required for full activation of the loci where they bind.

The upstream and intragenic binding of Egr2 and Sox10 is similar to the enhancer pattern found in another highly expressed myelin gene, Mpz (Jang and Svaren, 2009). Finding this pattern leads us to hypothesize that this is a common mechanism of transcriptional activation. Perhaps these sites interact, altering the chromatin architecture and leading to transcriptional activa- tion through an unknown mechanism. Enhancer interaction may be promoted by the DNA bending properties of Sox 10 (Werner et al., 1995; Peirano and Wegner, 2000). Further work will be needed to determine whether these elements interact in vivo.

Although we have focused on Pmp22 transcriptional regulation, there is a large body of work on Pmp22 posttranscriptional regulation. Pmp22 protein is highly regulated and is turned over quickly by the proteasome (Pareek et al., 1997; Notterpek et al., 1999). A point mutation or extra copies of Pmp22 lead to an accumulation of the protein that overwhelms the degradation pathway, leading to the CMT1A phenotype (Fortun et al., 2003, 2006). In addition, recent studies of micro-RNAs have found that, whereas Pmp 22 mRNA is expressed in other tissues in addition to peripheral nerve, protein expression is much more selective because of the effects of micro-RNAs (Lau et al., 2008; Verrier et al., 2009). The expression of our transgenic construct in tissues other than sciatic nerve may reflect the lack of known micro RNA binding sites in the Pmp22 3' UTR.

Our finding of a new enhancer in PMP22 has significant therapeutic implications for peripheral neuropathies. It is possible that noncoding mutations in regulatory elements may be associated with human peripheral neuropathies. In addition, regulatory element polymorphisms may be a factor that contributes to the range of severity experienced by CMT1A patients. Finally, identification of key regulatory elements in the PMP22 gene is 
expected to contribute toward development of novel treatment strategies for CMT1A by facilitating identification of compounds that reduce PMP22 expression.

\section{References}

Adlkofer K, Martini R, Aguzzi A, Zielasek J, Toyka KV, Suter U (1995) Hypermyelination and demyelinating peripheral neuropathy in Pmp22deficient mice. Nat Genet 11:274-280.

Berger MF, Philippakis AA, Qureshi AM, He FS, Estep PW 3rd, Bulyk ML (2006) Compact, universal DNA microarrays to comprehensively determine transcription-factor binding site specificities. Nat Biotechnol 24:1429-1435.

Bondurand N, Girard M, Pingault V, Lemort N, Dubourg O, Goossens M (2001) Human Connexin 32, a gap junction protein altered in the $\mathrm{X}$-linked form of Charcot-Marie-Tooth disease, is directly regulated by the transcription factor SOX10. Hum Mol Genet 10:2783-2795.

Bosse F, Zoidl G, Wilms S, Gillen CP, Kuhn HG, Müller HW (1994) Differential expression of two mRNA species indicates a dual function of peripheral myelin protein PMP22 in cell growth and myelination. J Neurosci Res 37:529-537.

Britsch S, Goerich DE, Riethmacher D, Peirano RI, Rossner M, Nave KA, Birchmeier C, Wegner M (2001) The transcription factor Sox10 is a key regulator of peripheral glial development. Genes Dev 15:66-78.

Chance PF, Alderson MK, Leppig KA, Lensch MW, Matsunami N, Smith B, Swanson PD, Odelberg SJ, Disteche CM, Bird TD (1993) DNA deletion associated with hereditary neuropathy with liability to pressure palsies. Cell 72:143-151.

Choo Y, Castellanos A, García-Hernández B, Sánchez-García I, Klug A (1997) Promoter-specific activation of gene expression directed by bacteriophage-selected zinc fingers. J Mol Biol 273:525-532.

Decker L, Desmarquet-Trin-Dinh C, Taillebourg E, Ghislain J, Vallat JM, Charnay P (2006) Peripheral myelin maintenance is a dynamic process requiring constant Krox20 expression. J Neurosci 26:9771-9779.

Denarier E, Forghani R, Farhadi HF, Dib S, Dionne N, Friedman HC, Lepage P, Hudson TJ, Drouin R, Peterson A (2005) Functional organization of a Schwann cell enhancer. J Neurosci 25:11210-11217.

Felsenfeld G, Groudine M (2003) Controlling the double helix. Nature 421:448-453.

Finzsch M, Schreiner S, Kichko T, Reeh P, Tamm ER, Bösl MR, Meijer D, Wegner M (2010) Sox10 is required for Schwann cell identity and progression beyond the immature Schwann cell stage. J Cell Biol 189:701-712.

Forghani R, Garofalo L, Foran DR, Farhadi HF, Lepage P, Hudson TJ, Tretjakoff I, Valera P, Peterson A (2001) A distal upstream enhancer from the myelin basic protein gene regulates expression in myelin-forming schwann cells. J Neurosci 21:3780-3787.

Fortun J, Dunn WA Jr, Joy S, Li J, Notterpek L (2003) Emerging role for autophagy in the removal of aggresomes in Schwann cells. J Neurosci 23:10672-10680.

Fortun J, Go JC, Li J, Amici SA, Dunn WA Jr, Notterpek L (2006) Alterations in degradative pathways and protein aggregation in a neuropathy model based on PMP22 overexpression. Neurobiol Dis 22:153-164.

Ghislain J, Charnay P (2006) Control of myelination in Schwann cells: a Krox20 cis-regulatory element integrates Oct6, Brn2 and Sox10 activities. EMBO Rep 7:52-58.

Giresi PG, Lieb JD (2009) Isolation of active regulatory elements from eukaryotic chromatin using FAIRE (formaldehyde assisted isolation of regulatory elements). Methods 48:233-239.

Giresi PG, Kim J, McDaniell RM, Iyer VR, Lieb JD (2007) FAIRE (formaldehyde-assisted isolation of regulatory elements) isolates active regulatory elements from human chromatin. Genome Res 17:877-885.

Guennoun R, Benmessahel Y, Delespierre B, Gouézou M, Rajkowski KM, Baulieu EE, Schumacher M (2001) Progesterone stimulates Krox-20 gene expression in Schwann cells. Brain Res Mol Brain Res 90:75-82.

Hai M, Bidichandani SI, Patel PI (2001) Identification of a positive regulatory element in the myelin-specific promoter of the PMP22 gene. J Neurosci Res 65:508-519.

Hai M, Muja N, DeVries GH, Quarles RH, Patel PI (2002) Comparative analysis of Schwann cell lines as model systems for myelin gene transcription studies. J Neurosci Res 69:497-508.

Hogan GJ, Lee CK, Lieb JD (2006) Cell cycle-specified fluctuation of nucleosome occupancy at gene promoters. PLoS Genet 2:e158.
Huxley C, Passage E, Manson A, Putzu G, Figarella-Branger D, Pellissier JF, Fontés M (1996) Construction of a mouse model of Charcot-MarieTooth disease type 1A by pronuclear injection of human YAC DNA. Hum Mol Genet 5:563-569.

Huxley C, Passage E, Robertson AM, Youl B, Huston S, Manson A, SabéranDjoniedi D, Figarella-Branger D, Pellissier JF, Thomas PK, Fontés M (1998) Correlation between varying levels of PMP22 expression and the degree of demyelination and reduction in nerve conduction velocity in transgenic mice. Hum Mol Genet 7:449-458.

Jang SW, Svaren J (2009) Induction of myelin protein zero by early growth response 2 through upstream and intragenic elements. J Biol Chem 284:20111-20120.

Jang SW, LeBlanc SE, Roopra A, Wrabetz L, Svaren J (2006) In vivo detection of Egr2 binding to target genes during peripheral nerve myelination. J Neurochem 98:1678-1687.

Jang SW, Srinivasan R, Jones EA, Sun G, Keles S, Krueger C, Chang LW, Nagarajan R, Svaren J (2010) Locus-wide identification of Egr2/Krox20 regulatory targets in myelin genes. J Neurochem 115:1409-1420.

Jones EA, Jang SW, Mager GM, Chang LW, Srinivasan R, Gokey NG, Ward RM, Nagarajan R, Svaren J (2007) Interactions of Sox10 and Egr2 in myelin gene regulation. Neuron Glia Biology 3:377-387.

Kamaraju AK, Bertolotto C, Chebath J, Revel M (2002) Pax3 downregulation and shut-off of melanogenesis in melanoma B16/F10.9 by interleukin-6 receptor signaling. J Biol Chem 277:15132-15141.

Kaya F, Belin S, Bourgeois P, Micaleff J, Blin O, Fontés M (2007) Ascorbic acid inhibits PMP22 expression by reducing cAMP levels. Neuromuscul Disord 17:248-253.

Kothary R, Clapoff S, Brown A, Campbell R, Peterson A, Rossant J (1988) A transgene containing lacZ inserted into the dystonia locus is expressed in neural tube. Nature 335:435-437.

Kuhlbrodt K, Herbarth B, Sock E, Hermans-Borgmeyer I, Wegner M (1998) Sox10, a novel transcriptional modulator in glial cells. J Neurosci 18:237-250.

Lau P, Verrier JD, Nielsen JA, Johnson KR, Notterpek L, Hudson LD (2008) Identification of dynamically regulated microRNA and mRNA networks in developing oligodendrocytes. J Neurosci 28:11720-11730.

Le N, Nagarajan R, Wang JY, Araki T, Schmidt RE, Milbrandt J (2005a) Analysis of congenital hypomyelinating Egr2Lo/Lo nerves identifies Sox2 as an inhibitor of Schwann cell differentiation and myelination. Proc Natl Acad Sci U S A 102:2596-2601.

Le N, Nagarajan R, Wang JY, Svaren J, LaPash C, Araki T, Schmidt RE, Milbrandt J (2005b) Nab proteins are essential for peripheral nervous system myelination. Nat Neurosci 8:932-940.

LeBlanc SE, Jang SW, Ward RM, Wrabetz L, Svaren J (2006) Direct Regulation of Myelin Protein Zero Expression by the Egr2 Transactivator. J Biol Chem 281:5453-5460.

LeBlanc SE, Ward RM, Svaren J (2007) Neuropathy-associated Egr2 mutants disrupt cooperative activation of myelin protein zero by Egr 2 and Sox10. Mol Cell Biol 27:3521-3529.

Livak KJ, Schmittgen TD (2001) Analysis of relative gene expression data using real-time quantitative PCR and the 2(-delta delta $\mathrm{C}(\mathrm{T})$ ) method. Methods 25:402-408.

Lupski JR, de Oca-Luna RM, Slaugenhaupt S, Pentao L, Guzzetta V, Trask BJ, Saucedo-Cardenas O, Barker DF, Killian JM, Garcia CA, Chakravarti A, Patel PI (1991) DNA duplication associated with Charcot-Marie-Tooth disease type 1A. Cell 66:219-232.

Mager GM, Ward RM, Srinivasan R, Jang SW, Wrabetz L, Svaren J (2008) Active gene repression by the EGR2/NAB complex during peripheral nerve myelination. J Biol Chem 283:18187-18197.

Magnaghi V, Ballabio M, Roglio I, Melcangi RC (2007) Progesterone derivatives increase expression of Krox-20 and Sox-10 in rat Schwann cells. J Mol Neurosci 31:149-157.

Magyar JP, Martini R, Ruelicke T, Aguzzi A, Adlkofer K, Dembic Z, Zielasek J, Toyka KV, Suter U (1996) Impaired differentiation of Schwann cells in transgenic mice with increased PMP22 gene dosage. J Neurosci 16:5351-5360.

Maier M, Berger P, Suter U (2002) Understanding Schwann cell-neurone interactions: the key to Charcot-Marie-Tooth disease? J Anat 200:357-366.

Maier M, Castagner F, Berger P, Suter U (2003) Distinct elements of the peripheral myelin protein 22 (PMP22) promoter regulate expression in Schwann cells and sensory neurons. Mol Cell Neurosci 24:803-817. 
Mandemakers W, Zwart R, Jaegle M, Walbeehm E, Visser P, Grosveld F, Meijer D (2000) A distal Schwann cell-specific enhancer mediates axonal regulation of the Oct-6 transcription factor during peripheral nerve development and regeneration. EMBO J 19:2992-3003.

Nagarajan R, Svaren J, Le N, Araki T, Watson M, Milbrandt J (2001) EGR2 mutations in inherited neuropathies dominant-negatively inhibit myelin gene expression. Neuron 30:355-368.

Notterpek L, Snipes GJ, Shooter EM (1999) Temporal expression pattern of peripheral myelin protein 22 during in vivo and in vitro myelination. Glia 25:358-369.

Orfali W, Nicholson RN, Guiot MC, Peterson AC, Snipes GJ (2005) An $8.5-\mathrm{kb}$ segment of the PMP22 promoter responds to loss of axon signals during Wallerian degeneration, but does not respond to specific axonal signals during nerve regeneration. J Neurosci Res 80:37-46.

Pareek S, Notterpek L, Snipes GJ, Naef R, Sossin W, Laliberté J, Iacampo S, Suter U, Shooter EM, Murphy RA (1997) Neurons promote the translocation of peripheral myelin protein 22 into myelin. J Neurosci 17:7754-7762.

Passage E, Norreel JC, Noack-Fraissignes P, Sanguedolce V, Pizant J, Thirion X, Robaglia-Schlupp A, Pellissier JF, Fontés M (2004) Ascorbic acid treatment corrects the phenotype of a mouse model of Charcot-MarieTooth disease. Nat Med 10:396-401.

Peirano RI, Wegner M (2000) The glial transcription factor Sox10 binds to DNA both as monomer and dimer with different functional consequences. Nucleic Acids Res 28:3047-3055.

Perea J, Robertson A, Tolmachova T, Muddle J, King RH, Ponsford S, Thomas PK, Huxley C (2001) Induced myelination and demyelination in a conditional mouse model of Charcot-Marie-Tooth disease type 1A. Hum Mol Genet 10:1007-1018.

Reiprich S, Kriesch J, Schreiner S, Wegner M (2010) Activation of Krox20 gene expression by Sox10 in myelinating Schwann cells. J Neurochem 112:744-754.

Robertson AM, Perea J, McGuigan A, King RH, Muddle J, Gabreëls-Festen AA, Thomas PK, Huxley C (2002) Comparison of a new pmp22 transgenic mouse line with other mouse models and human patients with CMT1A. J Anat 200:377-390.

Rossant J, Zirngibl R, Cado D, Shago M, Giguère V (1991) Expression of a retinoic acid response element-hsplacZ transgene defines specific domains of transcriptional activity during mouse embryogenesis. Genes Dev 5:1333-1344.

Sabéran-Djoneidi D, Sanguedolce V, Assouline Z, Lévy N, Passage E, Fontés M (2000) Molecular dissection of the Schwann cell specific promoter of the PMP22 gene. Gene 248:223-231.
Schreiner S, Cossais F, Fischer K, Scholz S, Bösl MR, Holtmann B, Sendtner M, Wegner M (2007) Hypomorphic Sox10 alleles reveal novel protein functions and unravel developmental differences in glial lineages. Development 134:3271-3281.

Sereda M, Griffiths I, Pühlhofer A, Stewart H, Rossner MJ, Zimmerman F, Magyar JP, Schneider A, Hund E, Meinck HM, Suter U, Nave KA (1996) A transgenic rat model of Charcot-Marie-Tooth disease. Neuron 16:1049-1060.

Sereda MW, Meyer zu Hörste G, Suter U, Uzma N, Nave KA (2003) Therapeutic administration of progesterone antagonist in a model of CharcotMarie-Tooth disease (CMT-1A). Nat Med 9:1533-1537.

Slutsky SG, Kamaraju AK, Levy AM, Chebath J, Revel M (2003) Activation of myelin genes during transdifferentiation from melanoma to glial cell phenotype. J Biol Chem 278:8960-8968.

Snipes GJ, Suter U, Welcher AA, Shooter EM (1992) Characterization of a novel peripheral nervous system myelin protein (PMP-22/SR13). J Cell Biol 117:225-238.

Suter U, Scherer SS (2003) Disease mechanisms in inherited neuropathies. Nat Rev Neurosci 4:714-726.

Suter U, Snipes GJ, Schoener-Scott R, Welcher AA, Pareek S, Lupski JR, Murphy RA, Shooter EM, Patel PI (1994) Regulation of tissue-specific expression of alternative peripheral myelin protein-22 (PMP22) gene transcripts by two promoters. J Biol Chem 269:25795-25808.

Svaren J, Meijer D (2008) The molecular machinery of myelin gene transcription in Schwann cells. Glia 56:1541-1551.

Topilko P, Schneider-Maunoury S, Levi G, Baron-Van Evercooren A, Chennoufi AB, Seitanidou T, Babinet C, Charnay P (1994) Krox-20 controls myelination in the peripheral nervous system. Nature 371:796-799.

Verrier JD, Lau P, Hudson L, Murashov AK, Renne R, Notterpek L (2009) Peripheral myelin protein 22 is regulated post-transcriptionally by miRNA-29a. Glia 57:1265-1279.

Visel A, Blow MJ, Li Z, Zhang T, Akiyama JA, Holt A, Plajzer-Frick I, Shoukry M, Wright C, Chen F, Afzal V, Ren B, Rubin EM, Pennacchio LA (2009) ChIP-seq accurately predicts tissue-specific activity of enhancers. Nature 457:854-858.

Werner MH, Huth JR, Gronenborn AM, Clore GM (1995) Molecular basis of human 46X,Y sex reversal revealed from the three-dimensional solution structure of the human SRY-DNA complex. Cell 81:705-714

Zorick TS, Syroid DE, Arroyo E, Scherer SS, Lemke G (1996) The transcription factors SCIP and Krox-20 mark distinct stages and cell fates in Schwann cell differentiation. Mol Cell Neurosci 8:129-145. 